\title{
ジルコニア電解筫における酸素イオン伝诸に及ぼす応力の效果
}

\author{
栗原正也，荒木稚子，荒居善雄

\section{Stress effect on ionic conductivity of zirconia electrolyte} \\ Masaya Kuribara, Wakako Araki, Yoshio Arai \\ Graduate school of Science and Engineering, Saitama University \\ Shimookubo, Saitama-shi, Saitama, Japan

\begin{abstract}
The oxygen-ionic conductivity of yttria stabilized zirconia electrolyte subjected to the tensile stress was investigated in the present study. $14 \mathrm{~mol} \%$-yttria stabilized zirconia single crystal specimens were prepared. The tensile stress was applied in parallel to the crystal axes of the $\langle 100\rangle$ and $\langle 110\rangle$ directions at various temperatures. The applied tensile stress in both directions clearly increased the ionic conductivity. The improvement of the conductivity was large especially when the stress was applied in the $<100>$ direction and also at lower temperatures.
\end{abstract}

Key Words : Solid Oxide Fuel Cell, Ionic Conductivity, Tensile Stress Yttria Stabilized Zirconia

1. 緒

近年深刻化している環境問題を解決するため, 高効率で環 境負荷の小さいエネルギ一変換技術の開発が進められてい る. 中でも燃料電池は発電効率が高く，環境負荷が小さいと いう特徴を有する.

イットリア安定化ジルコニア (YSZ, Yttria Stabilized

Zirconia) は, 固体酸化物型然料電池（SOFC, Solid oxide fuel cell）の代表的な電解質である. SOFC単セルは，この電解質 および電極である燃料極と空気極より構成される. そのため セル作製の際には電極，電解質間に残留応力が発生し，また 高温下で稼動する際に電極と電解質の熱膨張率の差異によ り熱応力が発生する、しかし，現在までにこのような内部応 力が発電効率に与える影響については明らかにされていな い.

本研究では，SOFCの想定稼動温度である高温化で応力を 負荷し，応力のイオン伝導率への影響を明らかにすることを 目的とする

\section{2. 实 験}

\section{1 試験片}

YSZは $1273 K$ 程度の高温下において酸素イオンの良電体と

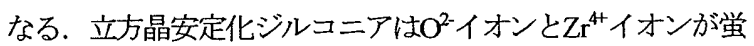
石型をとり，4 価のジルコニウムイオンの一部を 3 価のイッ トリムイオンで固溶置換して構造を安定化している. このと

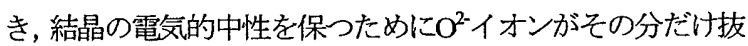
けて空格子点が出来る. 高温下においては， Oイオンはこの 空格子点を介して移動できるのでYSZは高い酸素イオン伝 導性を示す。

本研究では，安定化剂であるイットリウム含有量が $14 \mathrm{~mol} \%$ である単結晶体 2 種類を用いる．単結晶体は結晶方 位が異なり，それぞれ引張荷重方向に対して〈100〉，〈110〉 である.

試験片の形状を図 1 に示す。また，平行部の寸法を表 1 に 示す.

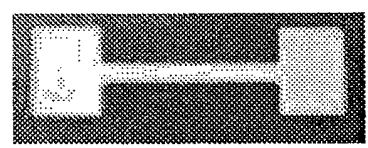

Fig.1 Specimen overview

日本機械学会 [No.10-9] M\&M2010 材料力学カンファレンス CD-ROM論文集〔2010.10.9-11,長岡] 
Table.1 Size of specimen

\begin{tabular}{lll}
\hline Span(mm) & Width $(\mathrm{mm})$ & Thickness $(\mathrm{mm})$ \\
\hline 1.5 & 0.1 & 0.1 \\
\hline
\end{tabular}

\section{2 実騟方法}

図 2 に引張荷重下での測定方法を示す，図のように試験片 を白金線で巻き，赤外線炉（アルバック理工株式会社 E410-P）内で試験片を引張試験機（島津製作所 AGS-H）と 接続したアルミナ製治具で挟み，ケミカルインピーダンスメ 一ター（3532-80 日置電気株式会社製）を使用し，交流4端 子法によるイオン伝導率の測定を行った.

負荷条件は, $1 \mathrm{~N}$ から $20 \mathrm{~N}$ の間で負荷, 除荷を3回繰り返す。 これを873K，973K，1073K，1173Kそれぞれで行う。

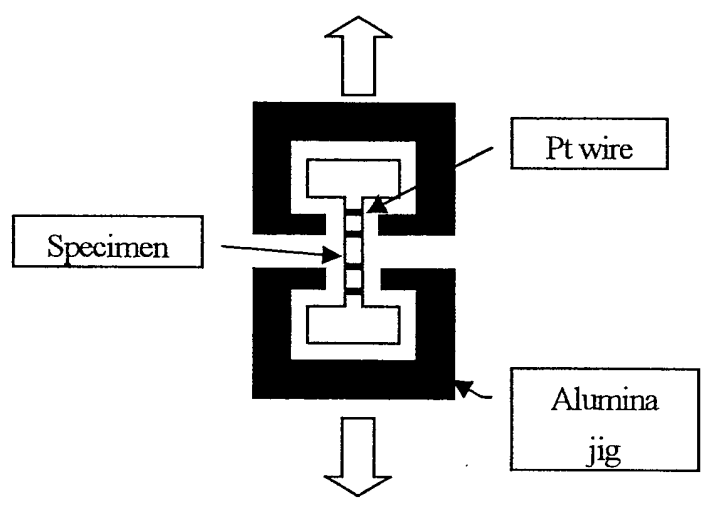

Fig 2 Schematic image of the experiment

\section{3. 実験結果}

図 3， 4 に<100>, <110>の 973K, 引張荷重下での忘 カーイオン伝導率の関係それぞれ示す。また，図 5 に 引張荷重下での测定温度における 1Nから 20N間のイ オン伝導率の変化率を示す。

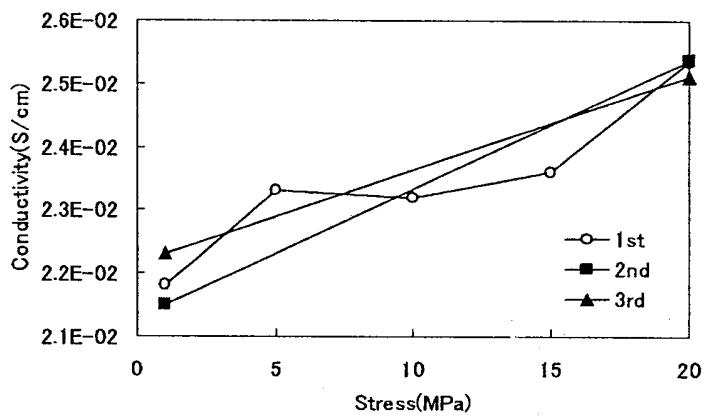

Fig. 3 Stress-ionic conductivity relationship of $<100>$ at $973 \mathrm{~K}$

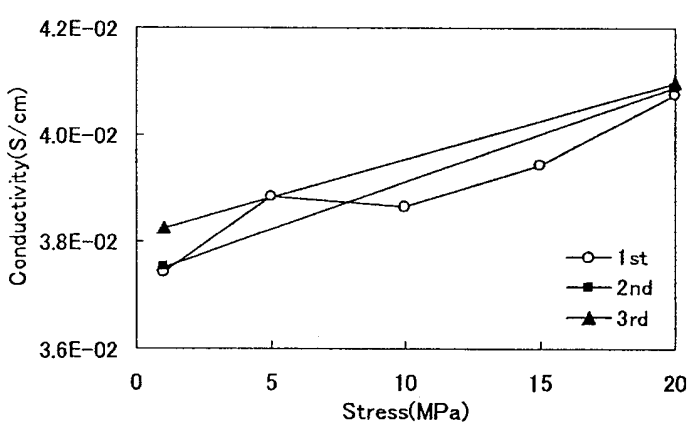

Fig 4 Stress-ionic conductivity relationship of $<110>$ at $973 \mathrm{~K}$

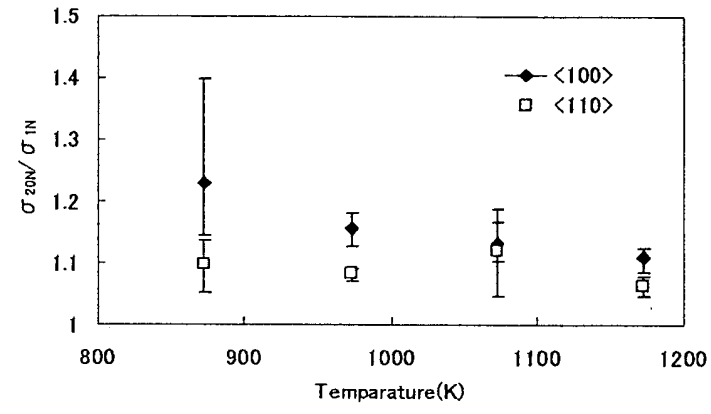

Fig. 5 Improvement of the conductivity by the tensile stress

$<100>,<110>0$ 引張荷重下では, どちらも応力の増加と 共にイオン伝導率肪向上することが分かる。

$1 \mathrm{~N}$ から 20N間のイオン伝首率の向上率は，<100 の方が <110>よりも大きく, 高温下よりも低温下の方が大きい傾向 がある.

この原因として考えられることは，YSZに引張荷重を負 荷することで，YSZ内で歪みが生じ，それか酸素イオンの 移動に促進に寄与したと考えられる。また低温下では，酸 素イオンとY+イオンとの複合体形成などにより，拡散係数 が低いとが，高、向上率こ関係すると考えられる.

\section{文献}

(1) Araki, W., Imai, Y., Adachi, T., Mechanical stress effect on oxygen ion mobility in $8 \mathrm{~mol} \%$ yttria stabilized zirconia electrolyte, Journal of the European ceramic society 29 (2009) 2275 2279

(2) Araki, W., Arai, Y., Oxygen diffusion in yttria stabilized zirconia subjected to uniaxial stress, Solid State Ionics 181 (2010) 441-446 